\title{
The typology of Muhammadiyah Sufism: tracing its figures' thoughts and exemplary lives
}

\author{
Biyanto
}

Faculty of Ushuluddin and Philosophy, State Islamic University Sunan Ampel Surabaya E-mail:mrbiyanto@gmail.com

DOI:10.18326/ijims.v7i2.221-249

\begin{abstract}
This article explores the style of sufism from the perspective of Muhammadiyah. It is a literature study on the official fatwa given by Muhammadiyah on sufism as a part of spiritual dimension in Islamic teaching. This study places a number of Muhammadiyah figures as the subject of study. This study concludes that the views of Muhammadiyah and its figures on sufism are very positive. Sufistic life in fact also becomes a trend among the followers of Muhammadiyah. Important styles of Muhammadiyah sufism include: first, Muhammadiyah sufistic teachings are based on pure monotheism. The second, Muhammadiyah sufistic is practiced under the frame of shari'ah, on the basis of the Qur'an and Hadith. Third, the substance of sufism in the Muhammadiyah perspective is noble character that should be realized in daily life. Fourth, the orientation of Muhammadiyah sufism emphasizes the dimension of righteous deeds, social praxis, and of moving from theory to practice. Fifth, Muhammadiyah sufism presents sufistic teachings adjusted to the spirit of modernity so that it may be called modern sufism. Sixth, Muhammadiyah sufism is expressed in more active and dynamic styles. A sufi is not allowed to do nothing, but is obliged to work actively and to interact with society. Seventh, Muhammadiyah
\end{abstract}


sufism stays away from the philosophical sufism discourse that may potentially cause debates. Muhammadiyah views that to become sufi, one should not become the member of sufi order with the style of "teacher-centered" in practice.

Artikel ini membahas corak sufisme dalam perspektif Muhammadiyah. Kajian ini merupakan studi literatur terhadap fatwa resmi Muhammadiyah terhadap sufisme sebagai bagian dari dimensi spiritual ajaran Islam. Kajian ini juga menempatkan sejumlah tokoh Muhammadiyah sebagai subjek studi. Kajian ini menyimpulkan bahwa perspektif Muhammadiyah dan tokoh-tokohnya terhadap sufisme sangat positif. Kehidupan sufistik dalam kenyataannya juga menjadi trend di kalangan pengikut Muhammadiyah. Corak sufisme Muhammadiyah yang penting meliputi: pertama, ajaran sufisme Muhammadiyah berbasis pada tauhid murni. Kedua, sufisme Muhammadiyah dipraktekkan dalam bingkai syariah, berdasar al-Qur'an dan hadits. Ketiga, substansi sufisme dalam perspektif Muhammadiyah adalah akhlak mulia dan harus diwujudkan dalam kehidupan sehari-hari. Keempat, orientasi sufisme Muhammadiyah menekankan dimensi amal salih, praksis sosial, dan bergerak dari teori ke praktek. Kelima, sufisme Muhammadiyah menampilkan ajaran tasawuf yang disesuaikan dengan spirit modernitas sehingga layak disebut tasawuf modern. Keenam, sufisme Muhammadiyah diekspresikan dalam corak yang lebih aktif dan dinamis. Seorang sufi tidak boleh berpangku tangan, melainkan harus aktif bekerja dan berinteraksi dengan masyarakat. Ketujuh, sufisme Muhammadiyah menjauhi wacana tasawuf falsafi yang potensial mengundang perdebatan. Terakhir, Muhammadiyah berpandangan untuk menjadi sufi, seseorang tidak harus menjadi anggota tarekat yang dalam prakteknya bercorak guru sentris.

Keywords: Progressive sufism; Sufi order; Muhammadiyah; ulama

\section{Introduction}

Discourse on sufism among the members of Muhammadiyah is felt less popular, since Muhammadiyah is a renewal movement carrying the spirit of purification in applying religious teachings. Some figures of Muhammadiyah also adopt a paradigm that sufism is one of the causes of 
the decline of the ummah. They perceive sufism as the phenomenon of backwardness. ${ }^{1}$ It is based on the historical reality showing that during the middle ages sufism had made the ummah lose their work ethos and spirits to develop sciences, whereas the development of an ummah is really determined by the work ethos and sciences. It is based on this understanding that the style of doing religious teachings in the form of sufism and sufi order (tariqah), is unpopular among the members of Muhammadiyah. ${ }^{2}$ This can be understood since Muhammadiyah was born under the atmosphere of the rise of Islam. Muhammadiyah since the beginning has also introduced itself as a movement to propagate Islam with spirit of progress. Muhammadiyah has also been widely known as the modernist Islamic movement.

The history and development of Muhammadiyah are inseparable from the founding father and originator of ideology, Ahmad Dahlan (18681923). Ahmad Dahlan (subsequently called Dahlan) is categorized as one of the figures of modernist Islam. He views that Islam is a religion with spirit to progress. The expression "spirit to progress" once was also popularized by Sukarno (1901-1970). In line with Dahlan, Sukarno resisted old-fashionedness, superstition, and polytheism. Sukarno criticized a religious model that easily calls others heathen, follows teachings blindly, accentuates Islamic law (figh), does not respect history, and likes to use weak Hadith as the guidance. The style of such a religious model is called Islam Sontoloyo. ${ }^{3}$ The view made by Sukarno is the result from his interac-

\footnotetext{
${ }^{1}$ Ahmad Nur Fuad, Dari Reformis Hingga Transformatif: Dialektika Intelektual Keagamaan Muhammadiyah, Malang: Intrans Publishing, 2015, 105-106.

${ }^{2}$ Syafiq A Mughni, "Tradisi Zuhud dan Sufisme dalam Muhammadiyah" in Hasnan Bachtiar (ed), Diskursus Neo-Sufisme Muhammadiyah: Genealogi, Konstruksi dan Manifestasi, Malang: Universitas Muhammadiyah Malang Press, 2015, 49.

${ }^{3}$ Sukarno, Islam Sontoloyo: Pikiran-Pikiran tentang Pembaharuan Islam, Yogyakarta: Sega Arsy, 2010.
} 
tions with Muhammadiyah figures, especially Dahlan dan Mas Mansur (1896-1946). When Sukarno was living in Surabaya, he was active to join in the study held by Dahlan. According to Dahlan, the ummah at that time was far behind and was lazy to catch up the lag due to takhayul (superstition) and bid'ah (heresy). The impact is that the ummah face difficulty to distinguish between the syncretic practices of local cultures and the true religious teachings.

Dahlan through his Muhammadiyah movement gave an emphasis on the importance of realizing Islamic modernism. Based on the background as a modernist movement, it is important to discuss sufism from the perspective of Muhammadiyah. The discussion would lead to official views on organization, thoughts, and exemplary model of Muhammadiyah figures. Religious views of Muhammadiyah, including sufism, as stated by the figures, are not monolithic in nature. The characteristics of religious views manifest in many faces. This conclusion refers to the research result made by Mitsuo Nakamura on the phenomenon of Muhammadiyah in Kotagede, Yogyakarta. ${ }^{4}$ He said that Muhammadiyah is an Islamic movement that seems exclusive viewed from the outer side, but it is actually very open. Organizationally, Muhammadiyah seems very impressive, but actually it is a group of individuals who respect personal devotion. Muhammadiyah also appears as an organization which is very discipline, although there is no effective tool to make it discipline, except the awareness among its members.

Muhammadiyah also seems aggressive and fanatical, though in the missionary endeavors it is very gradual and tolerant. Muhammadiyah is also impressed as anti-Java although in many aspects it inserts values of Java. Nakamura's conclusions are relevant to portrait the diversity of views

\footnotetext{
${ }^{4}$ Mitsuo Nakamura, "The Crescent Arises Over the Banyan Tree: A Study of Muhammadiyah in A Central Java," Dissertaion, Cornel University, 1976, 320-321.
} 
from Muhammadiyah figures on Sufism. ${ }^{5}$ Meanwhile in her work, Masyithoh Chusnan concludes that the sufism of Muhammadiyah is akhläqi (moral) in nature, as the Muhammadiyah leaders tend to emphasize the importance of practicing noble character in their daily life. ${ }^{6} \mathrm{Ahmad}$ Muttaqin asserts that although the sufi teachings of Muhammadiyah are not institutionalized in the form of sufi order (tarekat), they can be found in a number of official documents such as Kepribadian Muhammadiyah (The Personality of Muhammadiyah), Pedoman Hidup Islami Warga Muhammadiyah (Guidence of Islamic Life for Muhammadiyah Members), and Manhaj Tarjih Muhammadiyah (Methodology of Tarjih). ${ }^{7}$ In the same vein, Ahmad Nur Fuad maintains that although the figures of Muhammadiyah are not affiliated to certain tarekat, sufi practices are clearly discernible in their life. ${ }^{8}$ In this context study about sufism among the figures of Muhammadiyah is important. Figures of Muhammadiyah as the subject of this study are Ahmad Dahlan, Hamka (1908-1981), Abdul Rozak Fachruddin (1915-1995), and Abdurrahim Nur (1932-2008). Besides representing each generation, the four Muhammadiyah figures are also chosen since they have thoughts and exemplaries that may be related to sufistic life. It is through the official view of organization, thought and exemplary life of the figures that the typology of sufism from the perspective of Muhammadiyah may be concluded.

\footnotetext{
${ }^{5}$ Mitsuo Nakamura, "Sufi Elements in Muhammadiyah Noted from Field Observation," Prisma, Volume 9, Number 8 (1980), 1-16.

${ }^{6}$ Masyithoh Chusnan, "Meneropong Wajah Tasawuf dalam Muhammadiyah," http:// muhammadiyahstudies.blogspot.com. Accessed on October 17, 2017.

${ }^{7}$ Ahmad Muttaqin, "Muhammadiyah dan Sufisme," http://muhammadiyahstudies. blogspot.com. Accessed on October 14, 2017.

${ }^{8}$ Ahmad Nur Fuad, Dari Reformis..., 107.
} 


\section{Typology of Sufism in Islam}

Debates on sufism recently have occupied attention of the ummah, since sufism promises that the practicioners would get the deepness of meaning in religious life, serenity, and meaningful life. The term sufism is usually used by orientalist to name religious practices with mystical style in Islamic tradition. In general, the aim of sufism is to build dialogic relationships between the servant and God by going into seclusion and contemplation. Therefore, a sufi based on his own spiritual experiences may feel some closeness between himself and God, even, he feels united with Him (ittihād). ${ }^{9}$ During two centuries since Islam was born, tasawuf has been a spontaneous individual phenomenon. Those are called with the names of asceticists (zuhhād), worshippers (nussāk), al-Qur'an readers (qurra'), story tellers (qushshāsh), and the weepers (bukka')'. When sufism started to be established and known by the public, the term sufism is slowly replaced by zuhhād, nussāk, qurra', qushshäsh, dan bukkāa. ${ }^{10}$ In the development of sufism with individual characteristics accompanied with free reflection, it has changed into tariqah (sufi order), namely an organization or a place where sufis meet.

Theories on the origin of sufism principally can be grouped into two parts, namely sufism coming from non-Islamic teachings and sufism from the Islamic teachings. The elements from non-Islamic teachings strongly assumed to take part in forming the tradition of sufism are as follows. First is that it is the influence from Christian priesthood (rahbaniyyah). This opinion is mostly taken by the orientalist, such as Ignaz Goldziher (1850-1921) stating that the indigent attitude in the sufism teaching is a branch of the Christianity. The garments from wool worn by the sufi as 56.

${ }^{9}$ Harun Nasution, Falsafah dan Mistisisme dalam Islam, Jakarta: Bulan Bintang, 1985,

${ }^{10}$ Syafiq A. Mughni, Nilai-Nilai Islam: Perumusan Ajaran dan Upaya Aktualisasi, Yogyakarta: Pustaka Pelajar, 2001, 184. 
the symbol of simplicity are similar with those worn by the monks. Reynold Alleyne Nicholson (1868-1945) also stated that the term sufism in Islam is from Christianity. ${ }^{11}$ At a certain level, there is similarity between sufism and Christian priesthood teachings. But it does not mean that sufism is from the Christian tradition. It is in line with Mohammed Arkoun's (1928-2010) opinion that the zuhud and wara' way of life is a general tendency in all divine religions so that similarity between one religion and another is logical. ${ }^{12}$

Second is Persian element. Persian element here deals with the close relationship between Arab and Persia. Indeed, no proof is found about the argumentation that the spiritual life of Persia has entered into the region of Arab. Even what actually happens is the contrary, the spiritual life of Arab has come into Persia through Muslim sufis. In this situation, there must be a friction between Arab and Persian cultures. It is proved from the fact that there is a similarity in the concept of zuhud in Mau and Madag religions and zuhud in Islam. A similar concept of nature between Muhammad and the people in the Hurmuz in Zarathustha religion is also found.

Third is Greek element. The Greek mind, such as Pythagoras (570490 BC) and Plotinus' (204-270 BC) have given styles of sufi teachings. The philosophy of Pythagoras teaches that human spirit is eternal and holy, and it become dirty when it is tempted by the world life and is united with the body. Meanwhile, the happiness of the spirit is actually in the celestial nature. As result, in order to gain happiness in the celestial nature, human being should clean the spirit by leaving world pleasures and by making contemplation. Pythagoras' teaching has similarity with

\footnotetext{
${ }^{11}$ Abudin Nata, Akhlak Tasawuf, Jakarta: Rajawali Press, 1997, 185-187.

${ }^{12}$ Mohammed Arkoun, Rethinking Islam: Common Questions Uncommon Answers, Oxford: Wesview Press, 1994, 81.
} 
the concept of zuhud as practiced by sufis. The philosophy of Plotinus' emanation also states that being emanates from the Matter of the One Supreme God (emanation). Human spirit is also from God ad will return to Him. Since the spirit enters into the material nature, it becomes dirty, and to return into its original place it should be cleaned first. Purification of the spirit may only be made by leaving the world and getting closer to Him. This Plotinus' emanation philosophy clearly has similarity with the doctrine developed in Islamic philosophy and sufism.

Fourth is Indian elements. The similarity between the sufi teaching and Hinduism and Buddhism may be seen from the indigent attitude, reincarnation, and teaching to leave the world in order to get closer to God so that the unity between Atman and Brahman may be reached. The concept of $f a n a^{\prime}$ in tasawwuf seems similar with the teaching about nirwana in Hinduism and Buddhism. Even Goldziher states that there is a similarity between the story of spiritual life transition of sufi figures from Khurasan, Ibrahim Balkhi or Ibrahim bin 'Adam (718-782) and the repentance of Sidharta Buddha Gautama (563-483 BCE). ${ }^{13}$ There is a view that Indian elements as the origin of the sufism teaching are considered to be very extreme, because if sufism comes from Hinduism and Buddhist teachings, it means that during the era of the Prophet Muhammad, Hinduism and Buddhism have grown in Mecca. Indeed, this view is ahistorical.

Although there are many theories, but as concluded by Harun Nasution, sufism will still appear in Islamic tradition with or without influences from outside. ${ }^{14}$ Especially sufism, also mysticism in general, is teaching that exists in each religion. Evelyn Underhill shows that there are four

\footnotetext{
${ }^{13}$ A. J. Arberry, Pasang Surut Aliran Tasawuf, trans. by Bambang Herawan, Bandung: Mizan, 1989, 40.

${ }^{14}$ Harun Nasution, Falsafah dan Mistisisme..., 61.
} 
main characteristics of mysticism in each religious tradition, namely practical, transcendental, the mystic is a lover, and his object is union with the Absolute. ${ }^{15}$ Especially in the Islamic teachings, there are many verses of the Qur'an and Hadith that have given inspirations to the formation of a sufistic life pattern among the ummah of Islam. The confirmation of the Qur'an about the glory of the hereafter life over the world life is one of the motivations to live a sufistic lifestyle, as practiced by the sufis. Allah promises to give reward for those who are seriously trying to obtain the glory in the hereafter life, and on the contrary, to threat those who are lulled by the worldly life. ${ }^{16}$ Moreover, the life model of the Prophet Muhammad and his companions may also be seen as the normative-historical foundation of a Muslim who pursues a sufistic life.

The typology of sufism in general may be divided into three types, namely akhläqi (moral), 'amali (practical) and falsafi (philosophical). These three typologies are important to analyze the characteristics of Muhammadiyah sufism. Explicitly, Muhammadiyah goes against mystical practices organized in the form of sufi order since its teaching is centered on sufis teachers (murshid or shaikh). In sufi order, the obedience of the followers to the teacher is everything. A follower of sufi order should obey all things the teacher says. ${ }^{17}$ The pattern of being religious in the tradition of sufi order is unpopular in Muhammadiyah. Therefore, Muhammadiyah gives an emphasis on the use of mind to understand religion. Muhammadiyah also opposes to the sufism teachings contradicted to the main Islamic teachings. ${ }^{18}$ If the sufi teaching refers to the

${ }^{15}$ Evelyn Underhill, Mysticism: The Preminent Study in the Nature and Development of Spiritual Conciousness, New York: Image Books Doble Day, 1990, 70.

${ }^{16}$ Al-Qur'an, al-Hadid [57]: 19; al-Dhuhā [93]: 4; al-'Ankabūt [29]: 64; and al-Nazzi'ât [79]: 37.

${ }^{17}$ Syafiq A. Mughni, Nilai-Nilai Islam..., 281.

${ }^{18}$ Tim Pimpinan Pusat Muhammadiyah Majelis Tarjih, Tanya Jawab Agama Jilid II, Yogyakarta: Suara Muhammadiyah, 1992, 17. 
Qur'an and Sunnah, it means that it is allowed, therefore it should be implemented.

\section{Typology of Muhammadiyah Sufism}

The religious view made by Muhammadiyah always refers to the Qur'an and Hadith. According to Syamsul Anwar (b. 1956), this view is summarized in two important concepts, namely: purification and dynamicization. The formulation of the view, including sufism and sufi order, was decided through Tarjih and Tajdid assembly. ${ }^{19}$ It is in the process of decision making that the tendency of the purification and dynamicization may be clearly seen. A tough negotiation between purification and the modernization happened, Din Syamsuddin said (b. 1958). According to Din Syamsuddin, the desire to present pure Islam and spirit to the Qur'an and Hadith was too predominant in the religious view of Muhammadiyah. ${ }^{20}$ In formulating this view, Muhammadiyah does not give an emphasis on certain madhhab or school in Islam as the main referent. Syafiq Mughni (b. 1954) confirmed that he never determines whether it follows the concept of Jabariah or Qadariah theologies. Muhammadiyah also does not follow any madhhabs in the fields of Islamic law (figh) and sufism. It is intended that Muhammadiyah will not have any burden if it should respond the treasures of Muslim intellectual in the past. ${ }^{21}$ Therefore, the religious view of Muhammadiyah may be said to have a non-madhhab style.

\footnotetext{
${ }^{19}$ Syamsul Anwar, "Fatwa, Purification and Dinamization: A Study of Tarjih Muhammadiyah," Islamic Law and Society, Volume 12, Number 1 (2005), 27-44.

${ }^{20}$ M. Din Syamsuddin, "The Muhammadiyah Da'wah and Allocative Politics in New Order Indonesia," Studia Islamica Indonesian Journal for Islamic Studies, Volume 2, Number 2 (1995), 35-71.

${ }^{21}$ Syafiq A. Mughni, "Ahlussunnah Wal Jama'ah dan Posisi Teologi Muhammadiyah," in M. Din Syamsuddin (Ed), Muhammadiyah Kini dan Esok, Jakarta: Pustaka Panjimas, 1990, 259-280.
} 
The main basis of experiences of the religious teachings in Muhammadiyah is the Qur'an and Hadith. This religious view also applies for the fields of sufism and sufi order. For Muhammadiyah, sufism is a spiritual way one goes through to get closer to God. The stages taken are made by keeping away from any disgraceful acts (takhalli), habituating oneself to have good manners (tahalli), and getting as closer as possible to Allah so that the curtain that separates him from God (tajalli) is open. ${ }^{22}$ In practice, sufism is developing quickly to become sufi order. The sufi order teachings also place sufi teachers as the main referents in worshipping. Each sufi order has different sufi teacher. Therefore, the religious practices made by sufies and its tariqa followers are also different. Basing religious practices on certain spiritual teachers is not known in the view of Muhammadiyah. Muhammadiyah always asks to worship in accordance with the guidance the Qur'an and Hadith. Muhammadiyah also advocates the use of reason to understand the religious teachings. It means that Muhammadiyah is critical to sufism and sufi order schools. This attitude does not mean that Muhammadiyah is anti sufism and sufi order. For Muhammadiyah, the substance of sufism and sufi order is the teaching on the importance of noble character, while to evaluate one's noble character, one should refer to the Qur'an and Hadith. ${ }^{23}$ It is this religious view that is emphasized by Muhammadiyah figures from the early generations to the present time.

The most important figure in the early generation of Muhammadiyah is Ahmad Dahlan. This founding father and the ideologue of Muhammadiyah was born in Nitikan (most sources say Kauman), Yogyakarta. His nickname is Muhammad Darwis. He is from a family with the social background of santri and priyayi. His father, Abu Bakar, is

${ }^{22}$ Tim Pimpinan Pusat Muhammadiyah Majelis Tarjih, Tanya Jawab Agama..., 14.
${ }^{23}$ Tim Pimpinan Pusat Muhammadiyah Majelis Tarjih, Tanya Jawab Agama..., 17. 
the Imam (leader) of Masjid Agung Yogyakarta. His mother is Siti Aminah a daughter of Ibrahim, Penghulu Besar Yogyakarta. ${ }^{24}$ Ahmad Dahlan got religious education from his family, especially his father. He also pursued religious education at Islamic boarding schools in Java. Then, he went to Mecca in order to study religious education and also to do Hajj. He read books that are generally studied by the ulama from Indonesia and also from Mecca itself. He read books on al-tauhid with the concept of Ahl alSunnah wa al-Jama'ah. In the field of Islamic law (figh), he studied books written Shafi'iyah ulama. In the field of sufism, he read works written by Imam al-Ghazali. ${ }^{25}$ Coming home from the Mecca, he changed his name into Ahmad Dahlan. Since then, Ahmad Dahlan has been so well known in Kauman. ${ }^{26}$

In Mecca, Dahlan began to know Islamic thoughts from reformists. He learned Tafsir Al-Manar written by Rashid Rida (1865-1935), Tafsir Juz 'Amma, and al-Tauhid written by Muhammad 'Abduh (1849-1905), AlUrwah Al-Wuthqa written by Jamal al-Din Al-Afghani (1838-1897), and a number of books written by Ibn Taimiyah (1263-1328). ${ }^{27}$ The spirit to apply the ideas of reform was too incredible in his heart. He wanted to modernize the Islamic teachings to improve the backward life of the ummah. Therefore, he is known as the figure rich of ideas and desires. In the history of his life, Dahlan seems to do more real works than write good works in the form of books or others. Therefore, Solihin Salam calls Dahlan a working man ('amaliyat). His thoughts may be read through

\footnotetext{
${ }^{24}$ Kyai Syujak, Islam Berkemajuan: Kisah Perjuangan KH Ahmad Dahlan dan Muhammadiyah Masa Awal, Banten: Al-Wasath Publishing House, 2009, 3.

${ }^{25}$ K. R. H. Hadjid, Pelajaran KH A Dahlan: 7 Falsafah Ajaran $\mathcal{E} 17$ Kelompok Ayat AlQur'an, Yogyakarta: Lembaga Pustaka dan Informasi Pimpinan Pusat Muhammadiyah, 2008, 3.

${ }^{26}$ Ahmad Adaby Darban, Sejarah Kauman: Menguak Identitas Kampung Muhammadiyah, Yogyakarta: Tarawang, 2000, vii.

${ }^{27}$ K. R. H. Hadjid, Pelajaran KH A Dahlan..., 3.
} 
his activities he $\mathrm{did} .{ }^{28} \mathrm{He}$ always wanted to improve the condition of the society, especially dealing with religious practices and their social life. He emphasized the importance of the social dimension of the religious teachings such as mutual cooperation, giving charities to the poor and the orphan, mutual help, clear life, and the like. To his students, he taught social dimensions of the religious teachings with examples and direct practices.

For instance, Dahlan taught the interpretation of al-Qur'an verse $1-7 \mathrm{al}$ Ma ${ }^{i} u$ un repeatedly. He also wanted to obtain public fund as the theological basis for developing the social charity in Muhammadiyah. In this context, he may be called as the pioneer of the theology of al-Ma'unism. ${ }^{29}$ The spirit to practice the Islamic teachings seems to be so strong in his religious teachings to his students. One of his students, Muhammad Syujak (1885-1964) braced himself up asking, "Kyai, why are the surah al-Ma' ${ }^{\prime}$ un ad its interpretation lesson often repeated?" Dahlan answered, "Have you really understood it?" Syujak answered that his classmates and he himself had memorized and understood it. Dahlan then asked, "Have you acted on it?" Syujak answered that his classmates ad he himself had acted on it by reading the surah al-Ma' ${ }^{i}$ un when praying. Hearing this answer, Dahlan said that the intention of "acting" is to practice the content of surah al-Ma $\bar{a}^{i} \bar{u}$. To show the application of the context of the surrah al-Ma $\bar{a}^{c} \bar{u}$, Dahlan ordered his students to look for orphans and the poor. Then, Dahlan gave them soap to have a bath, clean clothes, food and beverages, and also shelters. ${ }^{30}$

Dahlan's understanding of his religious teachings with practical has inspired the establishment of various Muhammadiyah charity efforts in the field of education, health, economy, and social services. Dahlan has

\footnotetext{
${ }^{28}$ Solihin Salam, Muhammadiyah dan Kebangunan Islam di Indonesia, Jakarta: N. V. Miega, 1965, 45.

${ }^{29}$ Haedar Nashir, "Spirit Kelahiran Muhammadiyah," Suara Muhammadiyah, Number 10, Year 93 (May 16-31, 2008), 14.

${ }^{30}$ Anonim, "Melacak Akar Normatif Semangat al-Ma'un," Suara Muhammadiyah, Number 11, Year 90 (June 1-15, 2005), 7-8.
} 
inherited the struggle line of Muhammadiyah emphasizing the importance of social dimensions of religious teachings. He taught a faith with action. For Dahlan, religious teachings may not only be spoken in the podium, but should be practiced through concrete actions. The principles of real actions may be clearly seen in the dakwah made by Dahlan. So, there has been an orientation of religious ideology, instead of merely theories to practices. It is in this context that the slogan "talk less do more" was so popular among the early generation of Muhammadiyah. ${ }^{31}$ In this slogan there is belief that to be successful, sincerity and hard work are needed. From sufistic perspective, it can be said that Dahlan is a real model in applying Islamic teachings. He may model a sufistic life because of his sincerity, hard work, and other personal character.

Dahlan is also known to be precise, careful, to do in-depth studies, and to always try to make contextualization of the religious teachings in social life. His student, Hadjid (1897-1977), explained that the method adopted by Dahlan in understanding the Qur'an was tartil (reading) and tadabbur (thinking). What is thought is as follows: how is the meaning, how is the interpretation of the explanation, what is the meaning, whether this verse means prohibition and whether you left the prohibition, whether this verse means instruction that is obliged to be done, and have we done it? If the person reading the verse turns out that he has not really done it, according to Kyai Dahlan, he does need to read other verses. ${ }^{32}$ According to Ahmad Syafii Maarif (b. 1935), the method applied by Dahlan is very modern. However it is pity that this method is praised, but is not followed by Muhammadiyah ulama. ${ }^{33}$ Understanding

\footnotetext{
${ }^{31}$ Achmad Jainuri, Ideologi Kaum Reformis: Melacak Pandangan Keagamaan Muhammadiyah Periode Awal, trans. Ahmad Nur Fuad, Surabaya: LPAM, 2002, 209.

${ }^{32}$ KRH. Hadjid, Pelajaran KH. A. Dahlan..., 65.

${ }^{33}$ Ahmad Syafii Maarif, "Kyai Haji Mas Mansur: Manusia dengan Dimensi Ganda," in Amir Hamzah W (ed), KH. Mas Mansur Pemikiran tentang Islam dan Muhammadiyah, Yogyakarta-Malang: Hanindita dan YP2LPM, 1986, xxii.
} 
the depth of Dahlan religious knowledge and social sensitivity, Syafii Maarif stated that Dahlan is a person with double knowledge: religion and social reality. ${ }^{34}$ Contextualization of the religious teachings and social context as exemplified by Dahlan are very important to be the answer to the sufi expression that in general keeps the sufis away from social life.

The second generation of the Muhammadiyah figure who is worthy to be studied in their sufistic view is Haji Abdul Malik Karim Amrullah (Hamka). He is a figure whose expertise is encyclopedic. He is well known as expert in interpretation, preacher, scholar, politician, man of letters, and famous writer. He spent his childhood in Minangkabau, West Sumatra while learning religion in a little mosque (surau). He studied religion in Madrasah Diniyah Parabek (1916-1923). Then, he continued his study in Sumatera Thawalib. Since his childhood, Hamka often saw sharp disagreements between his father, a modernist, and his grandfather, a traditionalist. He was an autodidact in a lot of disciplines, such as philosophy, arts, history, sociology, and politics. His proficiency in Arabic made him able to review works from well-known writers in the East and the West. ${ }^{35}$

From his works, Tasawuf Modern and Tasawuf Perkembangan dan Pemurnian, represent his whole view on sufism in the modern context. Through these works, Hamka shows his love to the world of sufism. Hamka interpreted sufism as efforts to improve character and clean inner side. Sufism teaches one to start contemplation from oneself. Hamka cited an expression popular among the sufis; man 'arafa nafsahu faqad 'arafa rabbahu (Anyone understanding oneself must know his God). The sufism way also necessates the actor to clean himself using various exercises. It is expected that the longer one is trained to do noble characters,

${ }^{34}$ Ahmad Syafii Maarif, "Kyai Haji Mas Mansur”..., xxiii.

${ }^{35}$ Mustofa W. Hasyim, et.al, Ensiklopedi Muhammadiyah: Sejarah, Tokoh, dan Pemikiran, Yogyakarta: Majelis Ekonomi Kewirausahaan Pimpinan Wilayah Muhammadiyah DIY, LP3M UMY, Mata Bangsa, 2015, 397-398. 
the more open will be the hijab between himself and his God. ${ }^{36}$ Hamka confirmed that sufism is a human long-life need at all stages of developments of the society. However, Hamka reminded that the ummah should be careful with sufi teachers and spiritual teachers, who teach superstition, and all kinds of deception under the camouflage of religion. It is important to confirm that the practice of sufism in this modern era should still be oriented into the Qur'an and the Sunnah. It is this concept that is then known as modern sufism, namely sufism that has been adapted to the modernity context. ${ }^{37}$ Modern sufism means sufism with the basis of pure monotheism (tauhid), which is far from polytheism, bringing advancement, and teaching hard work.

The third generation of Muhammadiyah ulama living a sufistic life is Abdul Rozaq Fachruddin (well known as Pak AR). He is charismatic Muhammadiyah ulama. His lifestyle was very simple, always accentuated attitudes of patience, fortunate, tolerance, sincerity, and firmness in action. Pak AR really practiced sufi teaching in his daily life. As a well known ulama, a leader of a great organization of Muhammadiyah, and a figure close to the new order power, Pak AR could have become wealth. But nothing could shake his desire to live in a simple way. His sufistic life comes from his understanding of the essence of the religion of Islam. According to Pak AR, Islam is the religion of God which is passed to human beings with the medium of the prophet, the messenger of Allah. Human beings should practice the religious teachings, live in accordance with Allah's will, God who creates the earth and its contents, including all human beings. This understanding may bring about a faith that one's life is merely to accept. All things we have are given by Allah. They are merely entrusted to us. There are persons who are smart, rich, beautiful, and who

\footnotetext{
${ }^{36}$ Hamka, Pelajaran Agama Islam, Jakarta: Bulan Bintang, 1976, 33-35.

${ }^{37}$ Hamka, Tasawuf Modern, Jakarta: Pustaka Panjimas, 1991, 54.
} 
occupy high ranks, all are given by Allah. Human beings cannot refuse anything God gives. When they are asked for, human beings cannot refuse it. ${ }^{38}$ Pak AR's understanding was practically realized in his daily life.

Pak AR occupied the longest period of chairmanship of Muhammadiyah (1968-1990). Therefore, the members of Muhammadiyah really know Pak AR's personality and simplicity. Even the second president of Indonesia, Suharto (1921-2008), also admired his simplicity. Communication developed by Pak AR in leading Muhammadiyah was very polite. He was a successful leader in reducing some tension between the government and Muhammadiyah, especially in determining the single principle, Pancasila. Pak AR was also successful in encountering difficulties when the government issued a regulation that all civil servants were not allowed to be active in other organizations, including Muhammadiyah. Whereas, there were a lot of members of Muhammadiyah who worked as civil servants. Using a polite language style, Pak AR communicated with Suharto using a high level Javanese language (kromo inggil). ${ }^{39}$ This high level Javanese language is used as a strategy employed by Pak AR to build closeness with the government and also to smooth out the dakwah of Muhammadiyah.

The fourth generation of Muhammadiyah who is also sufistic is Abdurrahim Nur. Abdurrahim's early activity in Muhammadiyah occurred when he held the secretary of Majelis Tarjih of Muhammadiyah District Board of Sidoarjo in 1970. At last he became chairman of Muhammadiyah Provincial Board of East Java (1989-2000). ${ }^{40}$ The essence of sufism ac-

\footnotetext{
${ }^{38}$ AR. Rakhruddin, Soal Jawab yang Ringan-Ringan, Yogyakarta: Suara Muhammadiyah, 2012, 140.

${ }^{39}$ Nur Cholis Huda, Anekdot Tokoh-Tokoh Muhammadiyah, Surabaya: Hikmah Press, 2008, 28-30.

${ }^{40}$ A. Fatichuddin, et.al, Pergumulan Tokoh Muhammadiyah Menuju Sufi: Catatan Pemikiran Abdurrahim Nur, Surabaya: Hikmah Press, 2003, 12.
} 
cording to Abdurrahim cannot be separated from Islamic theology (tauhid) teachings, especially rubübiah and ulühiah. Rubübiah in this case is a doctrine dealing with faith in Allah as rabb (creator, organizer, keeper, and determiner) of the universe. The basic concept of rubübiah means that Allah is the rabb for the universe. ${ }^{41}$ It means that this universe as a whole without exception is created, organized, kept and determined by Allah in terms of the laws. Meanwhile, uluhiah means it makes Allah as God worshiped by all human beings (ilāh al-nās). ${ }^{42}$ In this case the word ilāh means worship. It is only Allah that should be worshipped. All forms of human worship should be oriented to Allah only. By worshipping in a correct way, it makes a servant has a faith in Allah as revealed by Allah: "No partner has He. And this I have been commanded and I am the first [among you] of the Muslims." 43

It is in this context that Abdurrahim stated that sufi behavior should be conducted by a sufi while he is still based on the teaching of rubübiyah and uluhiyah. It is important to emphasize that a sufi should adopt a correct Islamic theology shown through his ability to pray in line with the stipulations made by Allah and the Prophet. Moreover, as the foundation of monotheism spirit, all series of worship should be conducted sincerely and purely to Allah only. This emphasis is important since sometimes in the sufism behavior, the practice of worship is still polluted by seeds of polytheism so that it is contradicted with the tawheed spirit. Abdurrahim also paid attention to the results of contemplation made by mystical sufies who are well kown in the philosophical sufism teaching like Wahdatul Wujüd (wujudiyah). To evaluate the doctrine of the philosophical sufism, the best attitude is to return to the basic Islamic teachings on theology. ${ }^{44}$

\footnotetext{
${ }^{41}$ Al-Fätihah [1]: 1.

${ }^{42}$ Al-Nās [114]: 2.

${ }^{43}$ Al-An ‘ैam [6]: 163.

${ }^{44}$ A. Fatichuddin, et.al, Pergumulan Tokoh Muhammadiyah..., 54.
} 


\section{Interpreting typology of Muhammadiyah Sufism}

As a modern Islamic organization, Muhammadiyah places tasawuf as a form of very important practices of the teaching of Islam. For Muhammadiyah, tasawuf is an expression of the spiritual dimension of religious teachings. Based on the normative and historical bases, Muhammadiyah has a positive perspective on the existence of sufism. Especially the fact shows that actually there are a lot of members of Muhammadiyah who pursue sufistic lives. Mitsuo Nakamura said, the followers of Muhammadiyah may be categorized into three groups, namely salafi group that tends to be scriptural ad conservative; moderate group that combines puritanism and modernism, and liberal group. ${ }^{45}$ The members of Muhammadiyah have tendencies to sufistic life, especially those in the first and the second groups.

Muhammadiyah also gives strict directions about sufism. In Muhammadiyah perspective, sufism and sufi order in their various expressions should have strong foundations, either normative-theological or historical. The Qur'an and Hadith teachings and the exemplary life of the Prophet Muhammad and his companions are the main referents in pursuing a sufistic life. The condition of this modern society clearly demands a religious and meaningful life, because modernity often presents human life with materialistic, individualistic, and socially-alienated style. But to pursue a religious life is not easy, since it turns out that this modern era is also marked by rampant spiritualism practices which are not in line with Islamic teachings. The practices of new spiritualism, shamanism, the presence of spiritual teachers teach mysticism with heresy become threat to the religious ummah.

\footnotetext{
${ }^{45}$ Mitsuo Nakamura, “Identitas Muhammadiyah” in Abdul Mu'ti, et.al (Eds.), Kosmopolitanisme Islam Berkemajuan, Surakarta: Muhammadiyah University Press, 2016, 80-82.
} 
Through the examples of the figures' lives, Muhammadiyah presents a sufism style under the frame of charity movement. Dahlan and Pak AR clearly emphasize the importance of good deeds as the realization of religious teachings. The two Muhammadiyah figures are really not interested in complicated debates about sufism. For them, sufi teachings are not enough to be understood, but should be practiced in daily life. Character of Dahlan's sufi teachings shows the spirit to do the best to change the condition of the ummah of Islam that was still backward at that time. It is through Dahlan's activities that the Muhammadiyah charity efforts are beneficial for the interest of the ummah. Meanwhile, Pak AR presented sufistic teachings in the form of daily behaviors that seemed to be simple. Pak AR was also very accommodative with arts, local cultures, and the teachings of sufi order. The religious practices that are seen to be in line with the Muhammadiyah religious understandings could be changed by Pak AR without hurting the targets of the dakwah. Using specific methods ad proper cultural approach made Pak AR could be acceptable by the society.

Meanwhile, Hamka and Abdurrahim showed themselves as ulamascholars. The perspectives of the two Muhammadiyah figures on sufism seem to be very academic in nature. Sincerely, both figures realized that there is a very strong desire among the ummah to pursue a sufistic life in this modern era. However, the two ulamas were trying to limit the sufism discourse so that it would not enter into the category of philosophical sufism. For Hamka, the teachings of philosophical sufism are very dangerous for the ummah, since it does not only potentially trigger controversies, but the ummah with weak faith could be easily tempted by misleading sufi teachings. ${ }^{46}$ This view is based on in-depth study on Islamic literature that divides sufism into three categories namely: akhlāai, 'amali,

\footnotetext{
${ }^{46}$ Hamka, Tasawuf Perkembangan dan Pemurnian, Jakarta: Panjimas, 1984, 122-123.
} 
and falsafi. ${ }^{47}$ Although they are different, these three types of tasawuf actually only differ in the approaches adopted. Akhlāqi sufism uses morals approach where its stages consists of three namely takhalli, tahalli, dan tajalli, as explained above. Akhlāai sufism more accentuates the side of ethics and character education. Meanwhile, 'amali sufism uses action (dhikr) approach. This approach then reincarnates into sufi order. As the reincarnation of 'amati sufism, sufi order is successful in changing the type of sufism, where at the beginning it was merely individual movement and could be enjoyed by a certain religious elite, now it becomes a mass movement of the Muslim.

Sufism which was at first autonomous and independent individual contemplation and activities now becomes a close tie between teachers and students with teacher-centered pattern. ${ }^{48}$ This teacher-centered pattern then bears a culture of cult of an individual to the founder, builder and sufi order teacher. The position of teacher (murshid) is very important in sufi order. Each murshid even makes a continuous family tree up to the founder of sufi order, even the Prophet Muhammad. It is done by a murshid intending to make his tariqah included into a correct sufi order (mu'tabarah). ${ }^{49}$ Different from 'amali sufism, the type of the philosophical sufism adopts a rational approach. The philosophical sufism in general uses philosophical theories such as the concept of human being (anthropology), God and His relationship with human beings (theology), and universe (cosmology). The philosophical sufism often produces mystic-philosophical contemplations based on each sufi's experiences in his relationship with God. Therefore, we often find confessions given by a sufi who may directly relate to God, even unite with Him spiritually. It is

\footnotetext{
${ }^{47}$ Abudin Nata, Akhlak Tasawuf.., 17-18.

${ }^{48}$ Simuh, Tasawuf dan Perkembangannya di Dunia Islam, Jakarta: Rajawali Press, 1996, 207.

${ }^{49}$ Aboebakar Atjeh, Pengantar Sejarah Sufi dan Tasawuf, Solo: Ramadhani, 1994, 64.
} 
in this context that mystical doctrines develops in philosophical sufism, such as mystical union (wujüdiyah).

The understanding of sufistic teachings using a philosophical approach often bears a doctrine which is literally contradicted with the circle of orthodox Islam (ahl al-shari'ah). The contradiction between the mystic-sufi and shari'ah experts may be seen as conflicts between esoteric and exoteric, between heterodox and orthodox. Even, the philosophical teachings often raise controversies since they are considered not to be in line with monotheism in the Qur'an and Hadith..$^{50}$ Among the teaching of philosophical sufism that raise endless controversies is wah\}dat al-wujud initiated by Ibn 'Arabi. Some people evaluate that wah\}dat al-wuju'd is pantheistic in style so it is considered to be in contradiction with the spirit of Islamic monotheism. Some others think that the teaching actually has a strong historical and theological foundation in the Qur'an and Hadith. Since the philosophical sufism has resulted in endless polemics among the ummah, Muhammadiyah ulama has given a way out. According to Hamka, whatever the style, sufism should still be returned to the Islamic teachings as guided in the Qur'an and exemplary life of the Prophet Muhammad. ${ }^{51}$

Sufi teachers should protect the ummah from less useful debates, especially if the debate is confusing so that it may trigger conflicts among the ummah. What is needed to emphasize in each form of Sufism is its substance, namely making the actors possess noble character. In this context, Abdurrahim emphasized the importance of efforts in returning sufi teachings to be still under the frame of shari'ah. Therefore, it can be said that Abdurrahim has employed strategies that are similar with those employed by al-Ghazali. ${ }^{52}$ Hamka and Abdurrahim also seem to follow

\footnotetext{
${ }^{50}$ Fazlurrahman, Islam, Chicago: The University of Chicago Press, 1979, 212-213.

${ }^{51}$ Hamka, Tasawuf Perkembangan..., 46.

${ }^{52}$ Azyumardi Azra, Jaringan Ulama Timur Tengah dan Kepulauan Nusantara Abad XVII dan XVIII, Bandung: Mizan, 1995, 267.
} 
Ibn Taimiyah to purify sufism from misleading practices. Hamka clearly criticized sufism, sufi order shaikh, and spiritual teachers in the modern era who teach misleading religious experiences. Abdurrahim added that a sufi may possess individual experiences that tend to be elitist and unreasonable. But, something a sufi cannot leave is to pray as determined by Shari'ah. So, no sufi is allowed to think that he has been free from Shari'ah duties because he pursue sufistic behavior.

The matter of sufi order is also criticized by Muhammadiyah ulama. Each sufi order in general teaches practices dhikr and certain movements according to the teachings of the founders. Abdurrahim viewed that all series of worship in the sufi order should also be returned to the exemplary life of the Prophet Muhammad. He explained the existence of sufi order in the context of Islamic worship..$^{53}$ In Islamic worship, the Muslim ummah are not allowed to make herecy (bid'ah) dealing with the procedures. All procedures in worship have been determined by Allah and His Prophet. On the contrary, dealing with the worldly matter, the Muslim ummah are given freedom to make innovation as long as it is not contradictory to the basic principle of Islamic teachings. The question is whether worship done by sufi order teacher and his followers are included into pure worship (mahdah) or non special worship (ghairu mahdah). To answer this question, Abdurrahim exemplified teachings on dhikr dominating all sufi order schools. According to him, the substance of $d z i k r$ activities is to remember God. Therefore, doing dhikr is included into special worship, because the reading and the dhikr technique must be arranged in Islam.

Abdurrahim asked the ummah to criticize the dhikr practices in sufi orders. For example, there is a sufi order that teaches dhikr by reading a certain reading in a certain number. According to Abdurrahim, this teach-

${ }^{53}$ A. Fatichuddin, et.al, Pergumulan Tokoh Muhammadiyah..., 58. 
ing should be criticized, especially that dealing with the reading and the way of reading. For example, the Prophet Muhammad said that anyone who is at the end of life reads la ilāha illa allāh, he is assured to inter into the heaven. Based on the teaching, then there is a sufi order holding a mass dhikr program by reading lā ilāha illa allāh up to thousand times. According to Abdurahhim, what the Prophet Muhammad said should be understood under a more substantive perspective. According to him, the Prophet actually taught that the substance of the sentence là ilăha illa Allah may serve as the base in living this life. It means that it is not only an oral expression while doing dhikr. What is more important is the spirit to make the values contained the reading la iläha illa Allăh as the basis to do all activities. It is also important to emphasize in the daily life that we are able to prove that ourselves are persons with pure monotheism.

Based on the various perspectives, the typology of sufism for Muhammadiyah ulama is the willingness of a Muslim to accept, submit, abide, and obey fully to the stipulations made by Allah ad His Prophet. A sufi should be honest and pure in his monotheism. The worship a sufi does should also be in line with the examples given by the Prophet, not reduced or added. In other words, sufi teachings should be in line with the demands of the Qur'an and Hadith. This perspective should be given an emphasis because there are many people who think of sufism from their physical appearances such as thin body, shabby cloth, and staying away from the worldly enjoyment. Therefore, Abdurrahim criticized that sufies are merely diligent to do dhikr, even, until they are lovelorn as if they are experiencing ecstasy. According to Abdurrahim, the Prophet is the best person in all aspects. The Prophet Muhammad never did dhikr until he was "lovelorn" as a symbol of solemnity. The question is that whether there is someone who is more solemn in worship more than the Prophet. ${ }^{54}$

\footnotetext{
${ }^{54}$ A. Fatichuddin, et.al, Pergumulan Tokoh Muhammadiyah..., 60.
} 
This question should be answered by sufis who have experienced ecstasy when they were doing dhikr to Allah.

Sufism in the perspectives of Muhammadiyah figures is always related to the teachings of pure monotheism. The perspective of Abdurrahim on sufism is related to the teaching about destiny. According to Abdurrahim, God's destiny is very dynamic. ${ }^{55}$ Believing destiny should not cause the ummah to experience backwardness. The orientation of the understanding of sufism among the Muhammadiyah figures is praxis. It is the consequence of Muhammadiyah religious understanding emphasizing the importance of practical movement. As a result, a sufi should not do nothing, waiting for destiny, living alone, and staying away from the worldly life. On the contrary, a sufi should be always interacting with his social environment. He should also has a dynamic perspective on this world life. The perspectives adopted by Muhammadiyah figures that a sufi should become an activist seems in line with the concept of neosufism developed by Fazlurrahman. According to Fazlurrahman, neosufisme is a reformed sufism. ${ }^{56}$ Sufism developed by sufi teachers full of mystical-philosophical teachings as seen in the philosophical sufism is renewed by the teachings based on the Qur'an and Hadith. Neo-sufism also diverts on socio-moral reconstruction for Muslim society. It is clearly different from the tendency of sufism in the past which gave more emphasis on individual piety than social piety. Azyumardi Azra also concluded that the character of neo-sufism as stated by Fazlurrahman is puritanic and activist. ${ }^{57}$ It is the most important typology of Muhammadiyah sufism. Muhammadiyah sufism can be said as having practiced the essence of sufi

\footnotetext{
${ }^{55}$ Abdurrahim Nur, Percaya Pada Taqdir Membawa Kemajuan atau Kemunduran, Surabaya: Bina Ilmu, 1987, 40.

${ }^{56}$ Fazlurrahman, Islam..., 193-196; 205-206.

${ }^{57}$ Azyumardi Azra, "Neo-Sufisme dan Masa Depannya," in Muhammad Wahyuni Nafis (Ed), Rekonstruksi dan Renungan Religius Islam, Jakarta: Paramadina, 1996, 292.
} 
teachings, namely the noble character. That is in line with Khozin's conclution that the sufism of Muhammadiyah can be regarded as "sufi without tarekat". ${ }^{58}$

\section{Conclusion}

The views of Muhammadiyah studied here confirm the importance of sufism for the members of Muhammadiyah. They have presented a more substantive perspective on sufism. Sufism is not only understood as a teaching with theoretical nature, but becomes the ideological movement and is practiced in daily life. According to Muhammadiyah figures, the substance of sufistic life should be reflected the personality of each Muslim that may be observed through his morals. It means that the better the morality one has, the deeper his sufi qualification will be. Therefore, no wonder that the Muhammadiyah figures are widely known to be competent in religious knowledge, pious, humble, simple and egalitarian. Especially for egalitarian attitude, as practiced in their daily life, it shows the spirit that in Muhammadiyah there is no cult culture of someone. Even for Dahlan, individual cult is never taught in Muhammadiyah. This teaching also becomes critical to sufism practiced in each sufi order. Muhammadiyah and its figures also confirm that a sufi should still be based on pure monotheism teachings and should worship Allah in line with the demands of Shari'ah. It means that Muhammadiyah teaches moderate Sufism. It is a important step to make so that sufi behavior will not trigger controversies as taught by sufi figures with mystical-philosophical teachings. Moreover, a sufi should also active to work hard to get happiness. Sufism perspective with activist style is important since it is in line with the spirit of religious belief among the members of Muhammadiyah.

\footnotetext{
${ }^{58}$ Khozin, Sufi Tanpa Tarekat: Praksis Keagamaan Muslim Puritan, Malang: Intrans Publishing, 2013, 48-50.
} 


\section{Bibliography}

Anwar, Syamsul, "Fatwa, Purification and Dinamization: A Study of Tarjih Muhammadiyah," Islamic Law and Society, Volume 12, Number 1 (2005): 27 44.

Anonim. "Melacak Akar Normatif Semangat al-Ma'un," Suara Muhammadiyah, Number 11, Year 90 (June 1-15, 2005): 7-8.

Arkoun, Mohammed. Rethinking Islam: Common Questions Uncommon Answers. Oxford: Wesview Press, 1994.

Arberry, A. J. Pasang Surut Aliran Tasawuf. Trans. by Bambang Herawan. Bandung: Mizan, 1989.

Atjeh, Aboebakar. Pengantar Sejarah Sufi dan Tasawuf. Solo: Ramadhani, 1994.

Azra, Azyumardi. Jaringan Ulama Timur Tengah dan Kepulauan Nusantara Abad XVII dan XVIII. Bandung: Mizan, 1995.

Azra, Azyumardi. "Neo-Sufisme dan Masa Depannya," in Muhammad Wahyuni Nafis (Ed), Rekonstruksi dan Renungan Religius Islam. Jakarta: Paramadina, 1996.

Chusnan, Masyithoh. "Meneropong Wajah Tasawuf dalam Muhammadiyah," http://muhammadiyahstudies.blogspot.com.

Darban, Ahmad Adaby. Sejarah Kauman: Menguak Identitas Kampung Muhammadiyah. Yogyakarta: Tarawang, 2000.

Fakhruddin, AR. Soal Jawab yang Ringan-Ringan. Yogyakarta: Suara Muhammadiyah, 2012.

Fatichuddin, A., et.al. Pergumulan Tokoh Muhammadiyah Menuju Sufi: Catatan Pemikiran Abdurrahim Nur. Surabaya: Hikmah Press, 2003.

Fazlurrahman. Islam. Chicago: The University of Chicago Press, 1979.

Fuad, Ahmad Nur. Dari Reformis hingga Transformatif: Dialektika Intelektual Keagamaan Muhammadiyah, Malang: Intrans Publishing, 2015.

Hadjid, K. R. H. Pelajaran KH A Dahlan: 7 Falsafah Ajaran \& 17 Kelompok Ayat Al-Qur'an. Yogyakarta: Lembaga Pustaka dan Informasi Pimpinan Pusat Muhammadiyah, 2008.

Hamka. Pelajaran Agama Islam. Jakarta: Bulan Bintang, 1976.

Hamka. Tasawuf Modern. Jakarta: Pustaka Panjimas, 1991.

Hamka. Tasawuf Perkembangan dan Pemurnian. Jakarta: Panjimas, 1984.

Hasyim, Mustofa W. et.al. Ensiklopedi Muhammadiyah: Sejarah, Tokoh, dan Pemikiran.

Majelis Ekonomi Kewirausahaan Pimpinan Wilayah Muhammadiyah DIY, LP3M UMY. Mata Bangsa. Yogyakarta: LP3MUMY, 2015. 
Huda, Nur Cholis. Anekdot Tokoh-Tokoh Muhammadiyah. Surabaya: Hikmah Press, 2008.

Jainuri, Achmad. Ideologi Kaum Reformis: Melacak Pandangan Keagamaan Muhammadiyah Periode Awal, Trans. Ahmad Nur Fuad, Surabaya: LPAM, 2002.

Khozin. Sufi Tanpa Tarekat: Praksis Keagamaan Muslim Puritan. Malang: Intran Publishing, 2013.

Maarif, Ahmad Syafii, "Kyai Haji Mas Mansur: Manusia dengan Dimensi Ganda," in Amir Hamzah W (ed.). KH. Mas Mansur Pemikiran tentang Islam dan Muhammadiyah. Yogyakarta-Malang: Hanindita dan YP2LPM, 1986.

Mughni, Syafiq A., "Tradisi Zuhud dan Sufisme dalam Muhammadiyah" in Hasnan Bachtiar (ed.). Diskursus Neo-Sufisme Muhammadiyah: Genealogi, Konstruksi dan Manifestasi. Malang: Universitas Muhammadiyah Malang Press, 2015.

Mughni, Syafiq A. Nilai-Nilai Islam: Perumusan Ajaran dan Upaya Aktualisasi. Yogyakarta: Pustaka Pelajar, 2001, 184.

Mughni, Syafiq A., "Ahlussunnah Wal Jama'ah dan Posisi Teologi Muhammadiyah," in Din Syamsuddin (ed.). Muhammadiyah Kini dan Esok. Jakarta: Pustaka Panjimas, 1990, 259-280.

Muttaqin, Ahmad. "Muhammadiyah dan Sufisme," http://muhammadiyahstudies.blogspot.com.

Nakamura, Mitsuo. "The Crescent Arises Over the Banyan Tree: A Study of Muhammadiyah in A Central Java," Dissertation, Cornel University, 1976.

Nakamura, Mitsuo, "Sufi Elements in Muhammadiyah Noted from Field Observation," Prisma, Volume 9, Number 8 (1980): 1-16.

Nakamura, Mitsuo, "Identitas Muhammadiyah" in Abdul Mu'ti, et.al (eds.). Kosmopolitanisme Islam Berkemajuan. Surakarta: Muhammadiyah University Press, 2016: 80-85.

Nashir, Haedar, "Spirit Kelahiran Muhammadiyah," Suara Muhammadiyah, Number 10, Year 93 (May 16-31, 2008), 14.

Nasution, Harun. Falsafah dan Mistisisme dalam Islam. Jakarta: Bulan Bintang, 1985, 56.

Nata, Abudin. Akhlak Tasawuf. Jakarta: Rajawali Press, 1997.

Nur, Abdurrahim. Percaya Pada Taqdir Membawa Kemajuan atau Kemunduran. Surabaya: Bina Ilmu, 1987. 
Salam, Solihin. Muhammadiyah dan Kebangunan Islam di Indonesia. Jakarta: N. V. Miega, 1965.

Simuh. Tasawuf dan Perkembangannya di Dunia Islam. Jakarta: Rajawali Press, 1996.

Sukarno. Islam Sontoloyo: Pikiran-Pikiran tentang Pembaharuan Islam. Yogyakarta: Sega Arsy, 2010.

Syamsuddin, M. Din, "The Muhammadiyah Da'wah and Allocative Politics in New Order Indonesia," Studia Islamika Indonesian Journal for Islamic Studies, Volume 2, Number 2 (1995): 35-71.

Syujak, Kyai. Islam Berkemajuan: Kisah Perjuangan KH Ahmad Dahlan dan Muhammadiyah Masa Awal. Banten: Al-Wasath Publishing House, 2009. Tim Pimpinan Pusat Muhammadiyah Majelis Tarjih. Tanya Jawab Agama Jilid II. Yogyakarta: Suara Muhammadiyah, 1992.

Underhill, Evelyn. Mysticism: The Preminent Study in the Nature and Development of Spiritual Conciousness. New York: Image Books Doble Day, 1990. 